\section{Australian Journal of \\ Crop Science}

AJCS 14(12):1905-1912 (2020)

doi: 10.21475/ajcs.20.14.12.2721

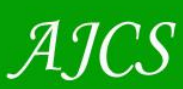

ISSN:1835-2707

\title{
Phenotypic correlations and path analysis between morphoagronomic and bromatological traits in corn hybrids for silage production
}

\author{
Jocarla Ambrosim Crevelari ${ }^{1}$, Nayara Norrene Lacerda Durães ${ }^{1}$, Gabriel Moreno Bernardo Gonçalves ${ }^{1}$, \\ José Arantes Ferreira Júnior ${ }^{1}$, Vivane Mirian Lanhellas Gonçalves ${ }^{1}$, Camila Queiroz da Silva Sanfim de \\ SantAnna ${ }^{2}$, Laila Cecília Ramos Bendia ${ }^{3}$, Flávio Henrique Vidal Azevedo ${ }^{3}$, Messias Gonzaga Pereira ${ }^{1}$
}

\author{
${ }^{1}$ Universidade Estadual do Norte Fluminense Darcy Ribeiro, Laboratório de Melhoramento Genético \\ Vegetal, Av. Alberto Lamego, 2000, Parque Califórnia, 28013-602, Campos dos Goytacazes, RJ, Brazil \\ ${ }^{2}$ Universidade Estadual do Norte Fluminense Darcy Ribeiro, Laboratório de Engenharia Agrícola, Av. \\ Alberto Lamego, 2000, Parque Califórnia, 28013-602, Campos dos Goytacazes, RJ, Brazil \\ ${ }^{3}$ Universidade Estadual do Norte Fluminense Darcy Ribeiro, Laboratório de Zootecnia, Av. Alberto \\ Lamego, 2000, Parque Califórnia, 28013-602, Campos dos Goytacazes, RJ, Brazil
}

\section{*Corresponding author: jcrevelari@yahoo.com.br}

\begin{abstract}
The aim of this study was to estimate the correlation coefficients and slicing the phenotypic correlations into direct and indirect effects by path analysis between morphoagronomic and bromatological traits in corn hybrids for silage. Nineteen topcross hybrids and five controls were assessed in a randomized block design with four replications in two environments (Campos dos Goytacazes and Itaocara, RJ), in the 2013/2014 agricultural year. Phenotypic correlations and path analysis were estimated between morphoagronomic (average plant height; average first ear height; average stem diameter; ear yield with husk at silage point; grain yield at silage point; green mass yield) and bromatological (dry matter; crude protein; neutral detergent fiber; lignin; crude fat and mineral matter) traits. The highest correlation estimates were obtained between dry matter and crude protein and between dry matter and neutral detergent fiber, with magnitudes of 0.97 and 0.98 , respectively. The coefficient of determination was high, indicating that the assessed components explain much of the variation in the dry matter content. Path analysis showed that traits with highest direct effect on dry matter content were the yield of green mass, crude protein, neutral detergent fiber, crude fat, and mineral matter associated to high correlations of $0.96,0.97,0.98,0.90$, and 0.96 , respectively. The results showed the possibility of obtaining significant gains through indirect selection.
\end{abstract}

Keywords: Indirect selection; Multicollinearity; Topcrosses; Zea mays L.

Abbreviations: $\mathrm{PH} \_$Average plant height; $\mathrm{EH} \_$average ear height; SD_average stem diameter; EY_ear yield with husk at silage point; GY_grain yield at silage point; GMY_green mass yield; DM_dry matter; CP_crude protein; NDF_neutral detergent fiber; LIG_lignin; CF_crude fat and MM_mineral matter.

Introduction

In plant breeding programs, several traits work at the same time, making it necessary to study the magnitude of relationships between characters of great relevance. Therefore, the knowledge of these changes in characters and also their correlations are very important during selection (Cruz and Carneiro, 2006).

Correlation between characters is one of the most important parameters for the genetic improvement of plants since it allows quantitative estimation of changes in a character that can influence the others in the evolutionary process through the selection. This fact is important when the simultaneous selection of characters or indirect selection is sought (Vieira et al., 2007).

Correlation coefficients, although are used in quantifying the magnitude and direction of the influences of factors in the determination of complex characters, do not draw conclusions about the cause and effect, not allowing for inferences to the type of association that governs the pair of characters $Y / X$ (Coimbra et al., 2005). These studies do not allow us to infer about the direct and indirect influences of characters that define the main character. Thus, studies on the slicing of the correlation coefficient are performed by path analysis (Cruz and Carneiro, 2006).

Wright (1921) developed the method of path analysis to reduce problems related to the interpretation of correlation coefficients. This method allows the correlation coefficient to be sliced into direct and indirect effects of a group of characters (explanatory variables) on the expression of the main variable (basic) of greater relevance for selection.

Path analysis has been successfully used in plant breeding of several crops and has been helping in the selection process of other species, such sunflower (Follmann et al., 2019), 
common bean (Cabral et al., 2011), elephantgrass (Daher et al., 2004), jabuticaba (Salla et al., 2015), sweet corn (Entringer et al., 2014), corn (Santos et al., 2018), soybean (Nicolai et al., 2017), and corn for silage (Crevelari et al., 2018).

The correlations between morphoagronomic and bromatological traits in corn for forage production are not yet elucidated and have great importance in the determination of strategies for selection in the crop breeding. However, the magnitude and value of correlations are not enough to clarify the relationships between groups of traits. In this sense, the detailed study of path analysis becomes necessary since the direct interpretation of magnitudes of correlations between traits can result in misunderstandings in the selection strategy (Cruz et al., 2012).

Developing corn genotypes for silage means the association regarding the superiority in bromatological and morphoagronomic traits, especially those related to the yield. Therefore, this study aimed to estimate the correlation coefficients and the slicing of phenotypic correlations into direct and indirect effects by means of the path analysis between morphoagronomic and bromatological traits in corn hybrids for silage.

\section{Results and Discussion}

\section{Analysis of variance and genetic parameters}

Significant effects $(p<0.01)$ and $(p<0.05)$, probability were observed for all studied traits indicating the existence of genetic variability among the genotypes. The effects of the interaction genotype $x$ environment were significant only for $\mathrm{PH}, \mathrm{SD}, \mathrm{GMY}$, and NDF indicating different responses among treatments in the evaluated environments (Table 2).

The coefficient of experimental variation (CVe) ranged from 5.54 to $23.12 \%$ and 23.02 to $27.49 \%$ for morphoagronomic and bromatological traits, respectively (Table 2). According to the classification of Fritsche-Neto (2012), the morphoagronomic traits had high experimental precision. However, other traits related to forage yield and quality presented higher values. This result was expected since these traits are strongly influenced by environmental conditions.

In addition, the heritability based on the mean varied from $48.30(\mathrm{EY})$ to $94.17 \%(\mathrm{PH})$ for morphoagronomic traits and from 54.85 (LIG) to $73.23 \%$ (MM) for bromatological traits (Table 2). With high values of heritability, the selection can be conducted with a great possibility of success for all traits of interest. Marcondes et al. (2012) considered heritability as the best parameter to make any inference on the success of the improvement in a character.

According to Ramalho et al. (2012), the higher the magnitude of accuracy is, the better the quality of the experiment and the greater the reliability of experimental information. In our study, selective accuracy was superior (0.69), indicating the possibility of success with the selection. Selective accuracy for morphoagronomic and bromatological traits ranged from high to very high (Ac $>0.78$ ), except for the traits EY, GY, LIG, and CF, which showed a moderate accuracy of $0.69,0.71,0.74$, and 0.77 , respectively (Table 2 ). An important aspect of selecting genotypes is the knowledge of the relationship between the assessed variables. The highly correlated traits allow the selection based on easier assessment, allowing a similar gain in the other trait (Cruz et al., 2012). Correlation estimates are a basic strategy for establishing guidelines for genetic breeding programs. These results allow obtaining gains for one of the traits through indirect selection, making the breeding process faster and more efficient (Alves et al., 2016).

\section{Correlations estimates}

The estimates of Pearson's phenotypic correlation ranged from $r=-0.46$ to $r=0.98$ (Fig 1). Morphoagronomic traits showed a significant and positive correlation with a high magnitude with most of the bromatological traits, showing that the former influence bromatological traits, i.e. they increase simultaneously.

The trait GMY showed the highest phenotypic correlation coefficients with DM, CP, NDF, LIG, CF, and MM, with values of $0.96 * * 0.94 * * 0.96 * * 0.93 * * 0.85^{* *}$, and $0.92^{* *}$, respectively (Fig 1 ). These high associations demonstrate high linear relationships between green mass yield and dry matter content, crude protein content, neutral detergent fiber, lignin, crude fat, and mineral matter.

However, the bromatological analyses carried out in the laboratory are costly and laborious for a breeding program that aims silage production, being essential to identify the morphoagronomic traits for quality silage. Furthermore, they need shortest time for assessment, cost, and advances in the development of new cultivars.

In addition, dry matter content showed positive and significant correlations with plant height $\left(0.54^{* *}\right)$, ear yield with husk at silage point $\left(0.87^{* *}\right)$, grain yield at silage point $\left(0.63^{* *}\right)$, and green mass yield $\left(0.96^{* *}\right)$ (Fig 1 ).

These estimates showed an association of inheritable nature among the assessed traits. Significant correlations indicate the possibility of indirect selection of important in breeding programs traits.

Moreover, the variables correlate positively with each other, showing the complexity of the relationship between traits that influence DM. The possibility of indirectly selecting plants with higher $\mathrm{PH}, \mathrm{EY}, \mathrm{GY}$, and GMY when a higher DM is desired (Fig 1).

The knowledge of the correlation between characters is very important in genetic breeding programs since it facilitates the selection. The study of relationships among the traits allows directing the selection, favoring the traits related to yield and quality of the most correlated forage (Gomes et al., 2004).

The correlations between morphoagronomic and bromatological traits in the production of corn for silage have not yet been explained and are of great importance in the definition of selection strategies for crop improvement. However, the magnitude and value of the correlations are not sufficient to clarify the relationships between traits since there may be no real relation of cause and effect. For this purpose, studies on the slicing of the correlation coefficient are performed by means of the path analysis, which aims to slice correlations into direct and indirect effects of the studied variables on the main variable (Cruz et al., 2012).

\section{Path analysis}

The results of path analysis involving the main variable DM as a function of the explanatory variables $P H, E H, S D, E Y, G Y$, GMY, CP, NDF, LIG, CF, and MM are shown in Table 3.

The coefficient of determination $\left(R^{2}\right)$ of the model of path analysis showed a magnitude of 0.9836 , indicating that $98.36 \%$ of the variation of the dependent variable DM in the 
Table 1. Identification of the twenty-five hybrids used in the experiments. Campos dos Goytacazes and Itaocara, RJ, in the 2013/2014 agricultural year.

\begin{tabular}{|c|c|c|c|}
\hline Identification & Hybrids & Heterotic group & Genetic basis \\
\hline 1 & UENF-2194* & Dent & Lines \\
\hline 2 & UENF-2195* & Dent & Lines \\
\hline 3 & UENF-2199* & Dent & Lines \\
\hline 4 & UENF-2205* & Dent & Population \\
\hline 5 & UENF-2198* & Dent & Lines \\
\hline 6 & UENF-2203* & Dent & Population \\
\hline 7 & UENF-2192* & Dent & Lines \\
\hline 8 & UENF-2206* & Dent & Population \\
\hline 9 & UENF-2207* & Dent & Population \\
\hline 10 & UENF-2208* & Dent & Lines \\
\hline 11 & UENF-2209* & Dent & Lines \\
\hline 12 & UENF-2210* & Dent & Population \\
\hline 13 & UENF- 2200* & Dent & Population \\
\hline 14 & UENF-2202* & Dent & Population \\
\hline 15 & UENF-2201* & Dent & Population \\
\hline 16 & UENF-2204* & Dent & Population \\
\hline 17 & UENF-2193* & Dent & Lines \\
\hline 18 & UENF-2191* & Dent & Lines \\
\hline 19 & Piranão $13^{*}$ & Dent & Population \\
\hline 20 & AG 1051** & Dent & Hybrid double \\
\hline 21 & UENF-2197** & Semi-dent & Lines \\
\hline 22 & UENF-2196** & Semi-dent & Lines \\
\hline 23 & $\mathrm{Br} 106^{* *}$ & Semi-dent & Population \\
\hline 24 & UENF $506-11 * *$ & Semi-dent & $\mathrm{IPH}$ \\
\hline 25 & Piranão $12 * * *$ & Dent & Population \\
\hline
\end{tabular}

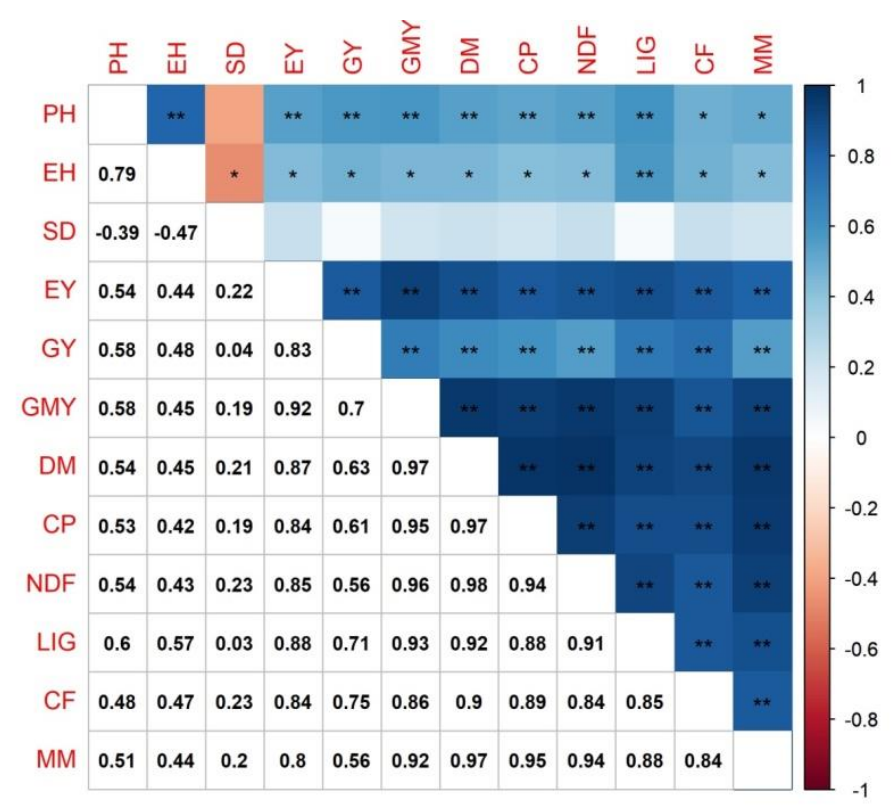

Fig 1. Estimates of the coefficients of phenotypic Pearson's correlations applied to traits morphoagronomic and bromatological in corn hybrids for silage production. Campos dos Goytacazes and Itaocara, RJ, in the 2013/2014 agricultural year. Average plant height (PH) in $\mathrm{m}$; average first ear height (EH), in $\mathrm{m}$; average stem diameter (SD), in mm; ear yield with husk at silage point (EY), in $\mathrm{kg} \mathrm{ha}^{-1}$; grain yield at silage point (GY), in $\mathrm{kg} \mathrm{ha}^{-1}$; green mass yield (GMY), in $\mathrm{kg} \mathrm{ha}^{-1}$; dry matter (DM), in kg ha ${ }^{-1}$; crude protein (CP), in $\mathrm{kg} \mathrm{ha}^{-1}$; neutral detergent fiber (NDF), in $\mathrm{kg} \mathrm{ha}^{-1}$; lignin (LIG), in $\mathrm{kg} \mathrm{ha}^{-1}$; crude fat (CF), in $\mathrm{kg} \mathrm{ha}^{-1}$, and mineral matter (MM), in kg ha $^{-1} .{ }^{\text {ns }}$ : Not Significant by the t test; ${ }^{* *}$ : Significant $(p<0.01)$ by the test; ${ }^{*}$ : Significant $(p<0.05)$ by the t test. 


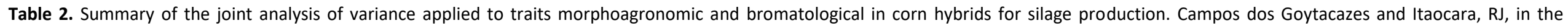
2013/2014 agricultural year.

\begin{tabular}{|c|c|c|c|c|c|c|c|}
\hline \multirow{3}{*}{ Variation sources } & \multirow{3}{*}{ DF } & \multicolumn{6}{|c|}{ Mean squares } \\
\hline & & $\mathrm{PH}$ & $\mathrm{EH}$ & SD & EY & GY & GMY \\
\hline & & \multicolumn{6}{|c|}{--------------------------------'Morphoagronomic----------------------------------- } \\
\hline Block/ Environment & 6 & 0.15058 & 0.10512 & 7.2901 & 7703347.81 & 2326959.02 & 30492784.42 \\
\hline Genotype (G) & 23 & $0.21463^{* *}$ & $0.13513^{* *}$ & $13.3324 * *$ & $11610599.83^{*}$ & $4328791.36 * *$ & $134884400.48^{* *}$ \\
\hline Environment $(A)$ & 1 & $0.3048^{\mathrm{ns}}$ & $0.06901^{\mathrm{ns}}$ & $730.4700 * *$ & $250189404.08^{\mathrm{ns}}$ & $51268834.50^{\text {ns }}$ & $746457228.0^{\mathrm{ns}}$ \\
\hline GXA & 23 & $0.07743 *$ & $0.01416^{\mathrm{ns}}$ & $4.7725^{*}$ & $7177267.64^{\mathrm{ns}}$ & $1829489.16^{\mathrm{ns}}$ & $70140897.07 *$ \\
\hline Error & 138 & 0.0125 & 0.01099 & 2.8877 & 6002445.40 & 2121672.55 & 42154841.64 \\
\hline General Average & & 2.01 & 1.26 & 22.49 & 11,758 & 6,298 & 31,774 \\
\hline $\mathrm{CV}_{\mathrm{e}}(\%)$ & & 5.54 & 8.29 & 7.55 & 20.83 & 23.12 & 20.43 \\
\hline $\mathrm{h}_{\overline{\mathrm{x}}}^{2}$ & & 94.17 & 91.86 & 78.34 & 48.30 & 50.98 & 68.74 \\
\hline \multirow[t]{2}{*}{$\hat{\mathrm{rggg}}$} & & 0.97 & 0.95 & 0.88 & 0.69 & 0.71 & 0.82 \\
\hline & & \multicolumn{6}{|l|}{ Mean squares } \\
\hline \multirow[t]{2}{*}{ Variation sources } & \multirow[t]{2}{*}{ DF } & DM & $\mathrm{CP}$ & NDF & LIG & $\mathrm{CF}$ & MM \\
\hline & & \multicolumn{6}{|c|}{ 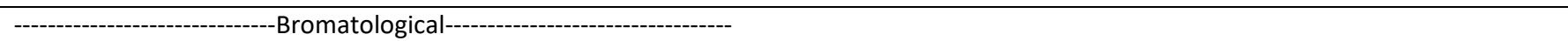 } \\
\hline Block/ Environment & 6 & 7311382.53 & 25421.55 & 2073165.86 & 19269.66 & 4634.52 & 24138.41 \\
\hline Genotype (G) & 23 & $24044017.30 * *$ & $126728.80 * *$ & $6317563.94 * *$ & $23075.28^{* *}$ & $6075.27^{* *}$ & $64491.05^{* *}$ \\
\hline Environment (A) & 1 & $155997365.75^{\mathrm{ns}}$ & $499290.00^{\mathrm{ns}}$ & $47096294.08^{\text {ns }}$ & $18703.25^{\mathrm{ns}}$ & $74655.18^{\text {ns }}$ & $87210.75^{\text {ns }}$ \\
\hline GXA & 23 & $11896023.36^{\text {ns }}$ & $57321.37^{\text {ns }}$ & $3934291.94 *$ & $16123.23^{\text {ns }}$ & $3329.26^{\text {ns }}$ & $21208.54^{\text {ns }}$ \\
\hline Error & 138 & 8236814.69 & 39222.88 & 2204457.08 & 10404.42 & 2468.68 & 17253.42 \\
\hline General Average & & 12,343 & 860 & 6,379 & 370 & 196 & 510 \\
\hline $\mathrm{CV}_{\mathrm{e}}(\%)$ & & 23.24 & 23.02 & 23.27 & 27.49 & 25.28 & 25.72 \\
\hline $\mathrm{h}_{\overline{\mathrm{x}}}^{2}$ & & 65.74 & 69.04 & 65.10 & 54.85 & 59.34 & 73.23 \\
\hline$\hat{\mathrm{rgg}}$ & & 0.81 & 0.83 & 0.80 & 0.74 & 0.77 & 0.85 \\
\hline
\end{tabular}




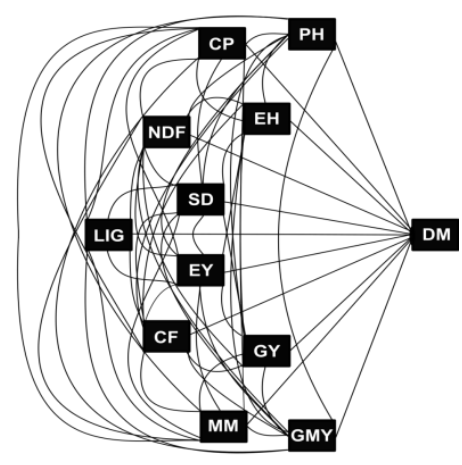

Fig 2. Schematic Fig into components of direct and indirect effects involving the main dependent variable (DM) and the independent explanatory variables (PH, EH, SD, EY, GY, GMY, CP, NDF, LIG, CF and MM) in corn hybrids for silage.

Table 3. Slicing of phenotypic correlations into components of direct and indirect effects involving the main dependent variable (DM) and the independent explanatory variables (PH, EH, SD, EY, GY, GMY, CP, NDF, LIG, CF and MM) in corn hybrids for silage. Campos dos Goytacazes and Itaocara, RJ, in the 2013/2014 agricultural year.

\begin{tabular}{|c|c|c|c|}
\hline $\mathrm{PH}$ & Estimate & $\mathrm{CP}$ & Estimate \\
\hline Direct effect on DM & 0.0206 & Direct effect on DM & 0.1314 \\
\hline Indirect effect via EH & -0.0169 & Indirect effect via PH & 0.0108 \\
\hline Indirect effect via SD & -0.0018 & Indirect effect via EH & -0.0090 \\
\hline Indirect effect via EY & 0.0151 & Indirect effect via SD & 0.0009 \\
\hline Indirect effect via GY & -0.0195 & Indirect effect via EY & 0.0232 \\
\hline Indirect effect via GMY & 0.0872 & Indirect effect via GY & -0.0206 \\
\hline Indirect effect via CP & 0.0693 & Indirect effect via GMY & 0.1413 \\
\hline Indirect effect via NDF & 0.1437 & Indirect effect via NDF & 0.2501 \\
\hline Indirect effect via LIG & 0.0465 & Indirect effect via LIG & 0.0690 \\
\hline Indirect effect via CF & 0.0856 & Indirect effect via CF & 0.1568 \\
\hline Indirect effect via MM & 0.1119 & Indirect effect via MM & 0.2098 \\
\hline Total & 0.54 & Total & 0.97 \\
\hline $\mathrm{EH}$ & & NDF & \\
\hline Direct effect on DM & -0.0214 & Direct effect on DM & 0.2660 \\
\hline Indirect effect via PH & 0.0163 & Indirect effect via PH & 0.0111 \\
\hline Indirect effect via SD & -0.0022 & Indirect effect via EH & -0.0092 \\
\hline Indirect effect via EY & 0.0121 & Indirect effect via SD & 0.0011 \\
\hline Indirect effect via GY & -0.0162 & Indirect effect via EY & 0.0237 \\
\hline Indirect effect via GMY & 0.0677 & Indirect effect via GY & -0.0188 \\
\hline Indirect effect via CP & 0.0552 & Indirect effect via GMY & 0.1434 \\
\hline Indirect effect via NDF & 0.1147 & Indirect effect via CP & 0.1235 \\
\hline Indirect effect via LIG & 0.0448 & Indirect effect via LIG & 0.0712 \\
\hline Indirect effect via CF & 0.0837 & Indirect effect via CF & 0.1488 \\
\hline Indirect effect via MM & 0.0969 & Indirect effect via MM & 0.2064 \\
\hline Total & 0.45 & Total & 0.98 \\
\hline SD & & LIG & \\
\hline Direct effect on DM & 0.0047 & Direct effect on DM & 0.0781 \\
\hline Indirect effect via PH & -0.0081 & Indirect effect via PH & 0.0122 \\
\hline Indirect effect via EH & 0.0100 & Indirect effect via EH & -0.0122 \\
\hline Indirect effect via EY & 0.0062 & Indirect effect via SD & 0.0001 \\
\hline Indirect effect via GY & -0.0013 & Indirect effect via EY & 0.0243 \\
\hline Indirect effect via GMY & 0.0291 & Indirect effect via GY & -0.0240 \\
\hline Indirect effect via CP & 0.0252 & Indirect effect via GMY & 0.1392 \\
\hline Indirect effect via NDF & 0.0615 & Indirect effect via CP & 0.1161 \\
\hline Indirect effect via LIG & 0.0023 & Indirect effect via NDF & 0.2424 \\
\hline Indirect effect via CF & 0.0397 & Indirect effect via CF & 0.1498 \\
\hline Indirect effect via MM & 0.0433 & Indirect effect via MM & 0.1931 \\
\hline Total & 0.21 & Total & 0.92 \\
\hline
\end{tabular}




\begin{tabular}{|c|c|c|c|}
\hline EY & & $\mathrm{CF}$ & \\
\hline Direct effect on DM & 0.0278 & Direct effect on DM & 0.1767 \\
\hline Indirect effect via PH & 0.0112 & Indirect effect via PH & 0.0100 \\
\hline Indirect effect via EH & -0.0093 & Indirect effect via EH & -0.0101 \\
\hline Indirect effect via SD & 0.0010 & Indirect effect via SD & 0.0010 \\
\hline Indirect effect via GY & -0.0282 & Indirect effect via EY & 0.0232 \\
\hline Indirect effect via GMY & 0.1378 & Indirect effect via GY & -0.0254 \\
\hline Indirect effect via CP & 0.1097 & Indirect effect via GMY & 0.1279 \\
\hline Indirect effect via NDF & 0.2269 & Indirect effect via CP & 0.1166 \\
\hline Indirect effect via LIG & 0.0685 & Indirect effect via NDF & 0.2240 \\
\hline Indirect effect via CF & 0.1475 & Indirect effect via LIG & 0.0662 \\
\hline Indirect effect via MM & 0.1767 & Indirect effect via MM & 0.1853 \\
\hline Total & 0.87 & Total & 0.90 \\
\hline GY & & MM & \\
\hline Direct effect on DM & -0.0338 & Direct effect on DM & 0.2206 \\
\hline Indirect effect via PH & 0.0119 & Indirect effect via PH & 0.0104 \\
\hline Indirect effect via EH & -0.0102 & Indirect effect via EH & -0.0094 \\
\hline Indirect effect via SD & 0.0001 & Indirect effect via SD & 0.0009 \\
\hline Indirect effect via EY & 0.0232 & Indirect effect via EY & 0.0222 \\
\hline Indirect effect via GMY & 0.1037 & Indirect effect via GY & -0.0189 \\
\hline Indirect effect via CP & 0.0801 & Indirect effect via GMY & 0.1373 \\
\hline Indirect effect via NDF & 0.1482 & Indirect effect via CP & 0.1250 \\
\hline Indirect effect via LIG & 0.0555 & Indirect effect via NDF & 0.2489 \\
\hline Indirect effect via CF & 0.1330 & Indirect effect via LIG & 0.0684 \\
\hline Indirect effect via MM & 0.1235 & Indirect effect via CF & 0.1484 \\
\hline Total & 0.63 & Total & 0.96 \\
\hline \multicolumn{4}{|l|}{ GMY } \\
\hline Direct effect on DM & 0.1492 & & \\
\hline Indirect effect via PH & 0.0120 & & \\
\hline Indirect effect via EH & -0.0097 & & \\
\hline Indirect effect via SD & 0.0009 & & \\
\hline Indirect effect via EY & 0.0257 & & \\
\hline Indirect effect via GY & -0.0235 & & \\
\hline Indirect effect via CP & 0.1245 & & \\
\hline Indirect effect via NDF & 0.2558 & & \\
\hline Indirect effect via LIG & 0.0729 & & \\
\hline Indirect effect via CF & 0.1514 & & \\
\hline Indirect effect via MM & 0.2031 & & \\
\hline Total & 0.96 & & \\
\hline Coefficient of determination & 0.9836 & & \\
\hline $\mathrm{K}$ value & 5.0662 & & \\
\hline Residual effect & 0.1277 & & \\
\hline
\end{tabular}

model is explained by the independent variables. For improvement purposes, it is extremely important to identify characters with a high correlation with the basic variable. Traits with the highest direct effect are favorable to selection so that the correlated response through indirect selection is effective (Cruz et al., 2006).

Table 3. shows that GMY, CP, NDF, CF, and MM presented direct effects with the same correlation signals, as well as high magnitudes, since they exceeded the estimate of the residual effect $(0.1277)$, with magnitudes of $0.1492,0.1374$, $0.2660,0.1767$, and 0.2206 , respectively.

This fact shows that the explanatory variables are the main determinants of variations in the main variable and, consequently, it is predicted that the indirect selection will be effective. Thus, for DM, the variables GMY, CP, NDF, CF, and $\mathrm{MM}$ stand out as the most associated with this character. Therefore, these variables have great importance in obtaining responses correlated with DM. Thus, it could select hybrids with higher GMY, CP, NDF, CF, and MM, which indirectly might select those that would provide a higher dry matter content. According to Cruz and Carneiro (2006), the use of indirect selection can accelerate the obtaining of promising genotypes since characters of easy measurement, high heritability, early measurement, and highly correlated with other characters are chosen. Although they are more important, but difficult to be obtained.

Crevelari et al. (2018) verified through path analysis that the character with the highest direct effect on green mass yield was ear yield with husk at silage point, associated with a high correlation $(r=0.91)$, demonstrating the possibility of obtaining significant gains with the indirect selection. Daher et al. (2004) verified that the traits number of tillers and tiller diameter explained the potential of dry matter production, acting in a direct and inversely proportional way, 
respectively, on the basic variable in napier grass.

Some variables, despite having a high association with the main variable, may not be a determining cause of variations on the character of interest. In this case, the concentration of efforts in the selection of this variable may not result in satisfactory gains in the main variable. The described situation is manifested in the relationship between DM and $\mathrm{PH}, \mathrm{DM}$ and EY, DM and LIG, in which the correlation between these variables is high, with values of $0.64,0.87$, and 0.92 , respectively. However, the direct effect of $\mathrm{PH}, \mathrm{EY}$, and LIG on DM does not exceed the magnitude of the residual effect (Table 3). Therefore, the intensified selection pressure on any of these variables may not provide satisfactory genetic gains in the dry matter content.

According to Cruz et al. (2012), characters with high favorable correlation, but with low direct effect, indicate that the best strategy should be the simultaneous selection of characters, with emphasis also on the characters whose indirect effects are significant. Although the variables EH and GY have shown a positive and statistically significant correlation with DM (Fig 1), the direct effects were negative, with values of -0.0214 and -0.0338 , respectively (Table 3 ). Thus, because the association between the characters was low, the simultaneous selection would probably not lead to a successful genetic gain. The intensified selection pressure on $\mathrm{EH}$ and GY may not provide satisfactory genetic gains on DM. In this situation, indirect and significant causal traits must be considered simultaneously in the selection process, as suggested by Cruz and Regazzi (1997).

Characters with a high favorable correlation with the basic variable, but with a direct effect in an unfavorable sense, indicates the absence of cause and effect. This means that the auxiliary character is not the main determinant of changes in the basic variable, and others may provide a higher impact in terms of selection (Cruz et al., 2006).

In this study, it is not intended to emphasize the difficulty in measuring the components related to dry matter content, but rather to propose a better understanding of how morphoagronomic and bromatological traits influence directly or indirectly dry matter content and suggest different choices of traits that can be selected in order to maximize the genetic gain with the selection, emphasizing silage production.

\section{Materials and methods}

\section{Plant materials and field experiments}

The genotypes came from the corn collection of the Darcy Ribeiro State University of Northern of Rio de Janeiro (UENF). Nineteen genotypes were selected from the heterotic group "Dent". Each genotype was crossed with a single tester, the Piranão 12 (Table 1).

Each genotype was grown in rows of $10.0 \mathrm{~m}$ in length, with an interrow spacing of $1.0 \mathrm{~m}$ and spaced $0.20 \mathrm{~m}$ from each other. During flowering, female parents were detasseled before ears release the stigma-styles in order to avoid contamination. Thus, stigma-styles received pollen only from the tester (Piranão 12). Harvesting was performed 120 days after sowing.

The tests of topcross hybrids were installed simultaneously at two environments: at the Antônio Sarlo Agricultural Technical School in Campos dos Goytacazes, RJ and Experimental Station of Ilha Barra do Pomba, in Itaocara, RJ, in the 2013/2014 agricultural year.
These environments are located at $21^{\circ} 24^{\prime} 48^{\prime \prime}$ South, $41^{\circ} 44^{\prime} 48^{\prime \prime}$ West, $14 \mathrm{~m}$ altitude, with mean rainfall $108.6 \mathrm{~mm}$ and mean temperature $27.27^{\circ} \mathrm{C}$; and at $21^{\circ} 40^{\prime} 09^{\prime \prime}$ South, $42^{\circ} 04^{\prime} 34^{\prime \prime}$ West, $60 \mathrm{~m}$ altitude, with mean rainfall $183.25 \mathrm{~mm}$ and mean temperature $25.32{ }^{\circ} \mathrm{C}$, respectively (INMET 2017). The experimental design was a randomized block design with four replications, each of them with 24 treatments, 19 topcross hybrids, and 5 controls (Table 1 ). The experimental unit consisted of a row of $5.0 \mathrm{~m}$ in length and interrow spacing of $1.0 \mathrm{~m}$, each of them with 25 plants per plot with a spacing of $0.20 \mathrm{~m}$ from each other. Three seeds were used per pit at a depth of $5 \mathrm{~cm}$. At 21 days after emergence, plants were thinned in order to keep one plant per pit. Sowing was carried out under a conventional planting system. Management practices were carried out as crop recommendations (Fancelli and Dourado Neto, 2000).

\section{Morphoagronomic and bromatological traits evaluated}

The following morphoagronomic traits were assessed: average plant height $(\mathrm{PH})$, measured from soil level up to the tassel insertion node, in $\mathrm{m}$; average first ear height (EH), measured from the soil level to the base of the upper ear in the stem, in $\mathrm{m}$; average stem diameter (SD), measured in the first internode above plant collar, in $\mathrm{mm}$; ear yield with husk at silage point (EY), in $\mathrm{kg} \mathrm{ha}^{-1}$; grain yield at silage point (GY), in $\mathrm{kg} \mathrm{ha}^{-1}$; and green mass yield (GMY), in kg ha ${ }^{-1}$.

The traits $\mathrm{PH}, \mathrm{EH}$, and $\mathrm{SD}$ were taken at random in six plants in the plot 80 days after planting. The traits EY, GY, and GMY were measured in 15 plants per plot, totaling $3.0 \mathrm{~m}$ of each row in the plot. Harvesting was carried out by cutting the plants at $20 \mathrm{~cm}$ from soil level, when grains were at the point called farinaceous ( $3 / 4$ of the milk line). EY was obtained by weighing the ears with husk at silage point. GY was obtained by weighing the threshed grains at silage point and GMY was obtained by weighing the plants (leaf + stem + cob + ear husk + grain) of each plot at the harvest time.

The bromatological analyses were performed at the Laboratory of Animal Science (LZO) of the Darcy Ribeiro State University of Northern of Rio de Janeiro in Campos dos Goytacazes, RJ. The following bromatological analyses were performed: dry matter (DM), crude protein (CP), neutral detergent fiber (NDF), crude fat (CF), lignin (LIG), and mineral matter (MM).

After harvest, a bundle with 15 plants was weighed, its ears removed, threshed, and the weight of grains recorded. The straw (leaf + stem + cob + ear husk) was processed in a chopper, homogenized, and a subsample was taken. Grain and straw samples were dried in a ventilated oven at $55{ }^{\circ} \mathrm{C}$ for 72 hours immediately after harvest. After drying, the samples (grains + straw) were ground into $1 \mathrm{~mm}$ in Wilye mills (Logen Scientific WLS-3004) to carry out the chemical analyses.

Forage samples were analyzed for total dry matter (Method 967.03, AOAC, 1990), crude fat (Method 2003.06) (Thiex et al., 2003), mineral matter (Method 942.05, AOAC, 1990), crude protein (Methods 984.13 and 2001.11) (AOAC, 1990); (Thiex et al., 2002), fibrous organic matter (Method 2002.04) (Mertens, 2002), and lignin (Method 973.18, AOAC, 1990) (Möller, 2009). All the bromatological variables (DM, CP, $\mathrm{NDF}, \mathrm{CF}, \mathrm{LIG}$, and MM) were transformed into $\mathrm{kg} \mathrm{ha}^{-1}$.

\section{Statistical analysis}

A joint variance analysis was performed for all evaluated traits. Estimates of mean squares, general average, 
coefficient of experimental variation, average heritability genotypes and accuracy were also calculated.

Phenotypic correlation estimates were obtained for all combinations of traits. The phenotypic correlations were then sliced into direct and indirect effects by means of the path analysis of Wright (1921), in which DM was the basic variable and the other morphoagronomic $(\mathrm{PH}, \mathrm{EH}, \mathrm{SD}, \mathrm{EY}$, $\mathrm{GY}$, and GMY) and bromatological variables (CB, NDF, LIG, $\mathrm{CF}$, and $\mathrm{MM}$ ) were considered the explanatory variables (Fig 2).

Before performing path analysis, the phenotypic correlation matrix was tested regarding the multicollinearity by the condition number of the matrix (CN), as proposed by Montgomery and Peck (1981), which is the ratio of the highest by the lowest eigenvalue of the matrix. In the presence of a moderate to strong $(100<\mathrm{CN}<1000)$ or severe multicollinearity ( $\mathrm{CN}>1000)$, the estimated walking coefficients are not reliable due to the high variances associated with their estimators (Carvalho and Cruz, 1996). However, in the presence of weak multicollinearity $(\mathrm{CN}<$ 100), there are no problems regarding the reliability of walking coefficients.

The methodology of Carvalho and Cruz (1996) was applied to measure the multicollinearity among the traits. However, multicollinearity presented $(\mathrm{CN}=2577.85)$ severe. This methodology consists of applying a constant $k$ to the diagonal matrix $X^{\prime} X$ of the ordinary least squares estimator. The applied $\mathrm{k}$ value was 5.0662 . The statistical analyses were performed using the software Genes (Cruz, 2013).

\section{Conclusions}

Plant height, ear yield with husk at silage point, grain yield at silage point, and green mass yield are strongly associated with dry matter content.

The coefficient of determination was high in the path analysis, indicating that the assessed morphoagronomic and bromatological traits explain a great part of the variation in dry matter content.

Green mass yield, crude protein content, neutral detergent fiber, crude fat, and mineral matter showed a high correlation and direct effect on dry matter content, which makes it an option of indirect selection.

\section{Acknowledgements}

The authors are grateful to the Research Support Foundation of Rio de Janeiro State (FAPERJ) for their financial support. This study was financed in part by the Coordenação de Aperfeiçoamento de Pessoal de Nível Superior - Brasil (CAPES) - Finance Code 001.

\section{References}

Alves BM, Cargnelutti Filho A, Burin C, Toebe M (2016) Correlações canônicas entre caracteres agronômicos e nutricionais proteicos e energéticos em genótipos de milho. Rev bras milho sorgo. 15: 171-185.

Cabral PDS, Soares TCB, Lima ABP, Soares YJB, Silva JA (2011) Análise de trilha do rendimento de grãos de feijoeiro (Phaseolus vulgaris L.) e seus componentes. Rev Ciênc Agron. 42: 132-138.

Carvalho SP, Cruz CD (1996) Diagnosis of multicollinearity: assessment of the condition of correlation matrices used in genetic studies. Braz J Genet. 19: 479-484.

Coimbra JLM, Benin G, Vieira EA, Oliveira AC, Carvalho FIF, Guindolin $A F$, Soares AP (2005) Consequências da multicolinearidade sobre a análise de trilha em canola. Cienc Rural. 35: 347-352.
Crevelari JA, Durães NNL, Bendia LCR, Vettorazzi JCF, Entringer GC, Ferreira Júnior JA, Pereira MG (2018) Correlations between agronomic traits and path analysis for silage production in maize hybrids. Bragantia. 77: 243-252.

Cruz CD (2013) Genes - a software package for analysis in experimental statistics and quantitative genetics. Acta Sci Agron. 35: 271-276.

Cruz CD, Regazzi AJ (1997) Modelos biométricos aplicados ao melhoramento genético. Viçosa: UFV 2: 390.

Cruz CD, Regazzi AJ, Carneiro PCS (2012) Modelos biométricos aplicados ao melhoramento genético. Viçosa: UFV 4: 514.

Cruz CD, Carneiro PCS (2006) Modelos biométricos aplicados ao melhoramento genético. Viçosa: UFV 2: 586.

Daher RF, Pereira AV, Pereira MG, Lédo FJS, Amaral Júnior AT, Rocabado JMA, Ferreira CF, Tardin FD (2004) Análise de trilha de caracteres forrageiros do capim-elefante (Pennisetum purpureum Schum.). Cienc Rural. 34: 1531-1535.

Entringer GC, Santos PHAD, Vettorazzi JCF, Cunha KS, Pereira MG (2014) Correlação e análise de trilha para componentes de produção de milho superdoce. Rev Ceres. 61: 356-361.

Fancelli AL, Dourado Neto D (2000) Produção de milho. Guaíba: Agropecuária 1: 360.

Follmann DN, Cargnelutti Filho A, Santos MS, Costa VO, Plautz EN, Scopel JVF, Bamberg DM, Engel GH, Olivoto T, Wartha CA, Nardino M (2019) Correlations and path analysis in sunflower grown at lower elevations. J Agric Sci. 11: 445-453.

Fritsche-Neto R, Vieira RA, Scapim CA, Miranda GV, Rezende LM (2012) Updating the ranking of the coefficients of variation from maize Experiments. Acta Sci Agron. 34: 99-101.

Gomes MS, Pinho RGV, Ramalho MAP, Ferreira DV, Brito AH (2004) Variabilidade genética em linhagens de milho nas características relacionadas com a produtividade de silagem. Pesq agropec bras. 39: 879-885.

Instituto Nacional de Meteorologia - INMET (2017). Available at: <http://www.inmet.gov.br/projetos/rede/pesquisa/instrucao.htm I>. Accessed on April 12, 2017.

Marcondes MM, Neumann M, Marafon F, Rosário JG, Faria MV (2012) Aspectos do melhoramento genético de milho para produção de silagem. Appl Res \& Agrotec. 5: 173-192.

Mertens DR (2002) Gravimetric determination of amylase-treated neutral detergent fiber in feeds with refluxing in beakers or crucibles: collaborative study. J AOAC Int. 85: 1217-1240.

Möller J (2009) Gravimetric determination of acid detergent fiber and lignin in feed: interlaboratory study. J AOAC Int. 92: 74-90.

Montgomery DC, Peck EA (1981) Introduction to linear regression analysis. New York, John Wiley e Sons.

Nicolai AB, Lima RC, Tomaz RS (2017) Phenotypic correlations and path analysis for agronomic productivity components of five soybean varieties, sown in the region of Alta Paulista. Revista Científica ANAP Brasil. 10: 80-91.

Ramalho MAP, Ferreira DF, Oliveira ACD (2012) Experimentação em genética e melhoramento de plantas. Lavras: UFLA 2: 305.

Salla VP, Danner MA, Citadin I, Sasso SAZ, Donazzolo J, Gil BV (2015) Análise de trilha em caracteres de frutos de jabuticabeira. Pesq agropec bras. 50: 218-223.

Santos WF, Vaz PCP, Haesbaert FM, Ferreira TPS, Sodré LF, Soares LB, Pereira JS (2018) Análise de trilha em genótipos de milho no Sul do Tocantins. Tecnol \& Ciên Agropec. 12: 49-52.

Thiex NJ, Anderson S, Gildemeister B (2003) Crude fat, hexanes extraction, in feed, cereal grain, and forage (randall/soxtec/submersion method): collaborative study. J AOAC Int. 86: 899-908.

Thiex NJ, Manson H, Anderson S, Persson JÁ (2002) Determination of crude protein in animal feed, forage, grain, and oilseeds by using block digestion with a copper catalyst and steam distillation into boric acid: collaborative study. J AOAC Int. 85: 309-317.

Vieira EA, Carvalho FIF, Oliveira AC, Martins LF, Benin G, Silva JAG, Coimbra J, Martins AF, Carvalho MF, Ribeiro G (2007) Análise de trilha entre os componentes primários e secundários do rendimento de grãos em trigo. Revista Brasileira Agrociência. 13: 169-174.

Wright S (1921) Correlation and causation. J Agric Res. 20: 557-585. 